\title{
Rekayasa Kamus Bahasa Jepang - Indonesia Menggunakan Bahasa Pemrograman Java
}

\author{
Azwar Anas \\ Jurusan Manajemen STIE - GK Muara Bulian \\ Kampus STIE- GK Muara Bulian, Jambi 36613 \\ Email: aans_07@yahoo.co.id
}

\begin{abstract}
ABSTRAK
Zaman telah berubah,era komputer telahmerambah keseluruh penjuru dunia. Tidak sebatas pada kegiatan ekonomi, militer, pemerintahan namun juga kegiatan pendidikan. Pendidikan merupakan langkah awal membangun masa depan yang lebih baik. Dengan mengenyam berbagai disiplin ilmu pengetahuan, maka seseorang dapat menentukan arah masa depannya dengan baik. Belajar selalu identik dengan sekolah sebagai salah satu sarana pendidikan formal yang disediakan pemerintah. Disekolah setiap siswa akan dididik menurut kurikulum yang telah ditetapkan pemerintah. Media yang digunakan biasanya adalah buku pelajaran yang disesuaikan dengan kurikulum pemerintah. Dari berbagai penelitian yang penulis lakukan, diantara kelemahan proses belajar mengajar khususnya pendidikan Bahasa Jepang adalah belum optimalnya penggunaan computer sebagai sarana penunjang kegiatan belajar. Para guru dan siswa masih menggunakan peralatan belajar manual seperti buku, kamus dan sumber-sumber referensi lainnya. Padahal computer sangat baik digunakan sebagai media belajar disamping untuk mengenalkan teknologi dikalangan pelajar dan umum. Berdasarkan persoalan diatas, penulis mencoba merekayasa sebuah media belajar dalam hal ini kamus sederhana dengan menggunakan bahasa pemrograman Java. Dengan harapan dapat mempermudah proses belajar mengajar baik disekolah maupun dirumah.
\end{abstract}

Kata kunci : Kamus, Java, Bahasa Jepang

\section{PENDAHULUAN}

\subsection{Latar Belakang Masalah}

Zaman telah berubah, era komputer telah merambah keseluruh penjuru dunia. Tidak sebatas pada kegiatan ekonomi, militer, pemerintahan namun juga kegiatan pendidikan. Pendidikan merupakan langkah awal membangun masa depan yang lebih baik. Dengan mengenyam berbagai disiplin ilmu pengetahuan, maka seseorang dapat menentukan arah masa depannya dengan baik. Belajar selalu identik dengan sekolah sebagai salah satu sarana pendidikan formal yang disediakan pemerintah. Di sekolah setiap siswa akan di didik menurut kurikulum yang telah ditetapkan pemerintah. Media yang digunakan biasanya adalah buku pelajaran yang disesuaikan dengan kurikulum pemerintah. Dari berbagai penelitianyang penulis lakukan, diantara kelemahan proses belajar mengajar khususnya pendidikan Bahasa Jepang adalah belum optimalnya penggunaan computer sebagai sarana penunjang kegiatan belajar. Para guru dan siswa masih menggunakan peralatan belajar manual seperti buku, kamus dan sumber-sumber referensi lainnya. Padahal computer sangat baik digunakan sebagai media belajar disamping untuk mengenalkan teknologi dikalangan pelajar dan umum. Berdasarkan persoalan diatas, penulis mencoba merekayasa sebuah media belajar dalam hal ini kamus sederhana dengan menggunakan bahasa pemrograman Java. Dengan harapan dapat mempermudah proses belajar mengajar baik disekolah maupun dirumah.

\subsection{Perumusan Masalah}

Adapun perumusan masalah

berdasarkan latar belakang diatas adalah:

1. Apakah Bahasa Pemrograman Java dapat merancang sebuah kamus Bahasa Jepang sederhana?

2. Apakah dengan penggunaan kamus Bahasa Jepang berbasis computer dapat 
meningkatkan minat belajar khususnya Bahasa Jepang?

3. Apakah dengan menggunakan komputer sebagai media belajar dapat meningkatkan dan mempermudah proses pembelajaran?

\subsection{Pembatasan Masalah}

Pendidikan Bahasa Jepang tentu tidaklah berbeda dengan pendidikan bahasa lainnya seperti Bahasa Indonesia, Inggris atau Arab. Dalam Bahasa Jepang juga akan dipelajari kosa-kata, struktur kalimat ataupun kesusatraan Jepang. Agar pembahasan lebih focus dan terarah maka dalam penelitian ini penulisannya membahas tentang kosa-kata Jepang yang terintegrasi dalam sebuah kamus sederhana berbasis komputer.

\subsection{Tujuan Penelitian}

Dalam melakukan penelitian ini ada beberapa tujuan yang ingin dicapai yaitu :

1. Memanfaatkan bahasa pemrograman Java

2. Merancang kamus Bahasa Jepang Indonesia sederhana

3. Mempermudah proses pembelajaran Bahasa Jepang

4. Memanfaatkan teknologi komputer

\section{LANDASAN TEORI}

\subsection{KonsepDasarSistemInformasi}

Diketahui bahwa informasi merupakan suatu hal yang sangat penting bagi manajemen dalam mengambil suatu keputusan.Yang menjadi pertanyaan adalah dari mana informasi tersebut diperoleh. Informasi diperoleh dari sistem informasi (InformationSystem).

Menurut Robert A. Leicth dan K. Roscoe Davis, "Sistem informasi adalah suatu sistem dalam suatu organisasi yang mempertemukan kebutuhan pengolahan transaksi harian, mendukung operasi, yang bersifat manajerial dan kegiatan-kegiatan strategi dari suatu organisasi.

\subsection{Komponen Sistem Informasi}

Sistem informasi terdiri dari beberapa komponen yang disebut dengan istilah Blok Bangunan, dan berikut ini adalah penjelasan tentang komponen Blok Bangunan tersebut yang digunakan untuk membantu analis dalam merancang sebuah aplikasi sistem informasi.

1. Blok masukan

Merupakan input yang mewakili data yang masuk kedalam sistem informasi.

2. Blok Model

Blok ini terdiri dari kombinasi prosedur, logika dan model matematik yang akan memanipulasikan data input dan data yang tersimpan dibasis data untuk menghasilkan keluaranyang diinginkan.

3. Blok Keluaran

Merupakan produk dari sistem informasi yang merupakan keluaran informasi dan dokumen yang berkualitas.

4. Blok Teknologi

Merupakan teknologi yang digunakan untuk menerima input, menjalankan model, menyimpan dan mengakses data, menghasilkan dan mengirimkan keluaran serta membantu pengendalian dari sistem secara keseluruhan.

5. Blok Basis Data

Merupakan kumpulan dari data-data yang saling berhubungan satu dengan lainnya, yang tersimpan diperangkat keras komputer.

6. Blok Kendali

Merupakan pengendalian yang dirancang untuk mengatasi dan mencegah kesalahan dan hal-hal yang dapat merusak sistem.

\section{METODOLOGI PENELITIAN}

\subsection{Pendahuluan}

Dalam melakukan sebuah penelitian, tentu harus berdasarkan metodologi penelitian yang benar sehingga dapat mempermudah jalannya penelitian tersebut. Metodologi penelitian merupakan kerangka kerja dalam melakukan penelitian. Dengan mengikuti kerangka kerja tersebut maka penelitian yang 


\section{Jurnal Edik Informatika}

dilakukan akan berjalan dengan sistematis dan memberikan hasil yang baik.

\subsection{Kerangka Kerja}

Pada bab ini akan diuraikan kerjangka kerja penelitian, kerangka kerja ini merupakan langkah-langkah yang akan dilakukan dalam penyelesaian masalah yang akan dibahas.

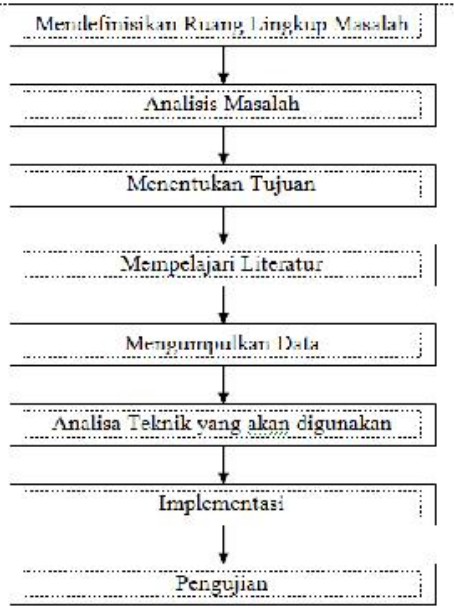

\section{Gambar 3.1. Kerangka Kerja Penelitan}

Berdasarkan kerangka kerja pada gambar 3.1. maka masing-masing langkahnya dapat diuraikan seperti berikut ini :

1. Mendefinisikan Ruang Lingkup Masalah. Ruang lingkup masalah yang akan diteliti harus ditentukan terlebih dahulu, karena tanpa mampu menentukan serta mendefinisikan batasan masalah yang akan diteliti, maka tidak akan pernah didapat suatu solusi yang terbaik dari masalah tersebut. Jadi langkah pertama ini adalah langkah awal yang terpenting dalam penulisan ini.

2. Analisis Masalah

Langkah analisis masalah adalah untuk dapat memahami masalah yang telah ditentukan ruang lingkup atau batasannya.Dengan menganalisa masalah yang telah ditentukan tersebut, maka diharapkan masalah dapat dipahami dengan baik.

3. Penentuan Tujuan
Berdasarkan pemahaman dari masalah, maka ditentukan tujuan yang akan dicapai dari penulisan ini. Pada tujuan ini ditentukan target yang dicapai, terutama yang dapat mengatasi masalah-masalah yang ada.

4. Mempelajari Literatur

Untuk mencapai tujuan, maka dipelajari berbagai literatur yang relevan dengna masalah yang diteliti. Kemudian literaturliteratur yang dipelajari tersebut diseleksi untuk dapat ditentukan literatur-literatur mana yang akan digunakan dalam penelitian.

Literatur diambil dari buku dan internet, yang berupa artikel dan jurnal ilmiah tentang sistem informasi, bahasa Jepang serta bahan bacaan lain yang mendukung penelitian.

5. Pengumpulan Data dan Informasi

Dalam pengumpulan data dilakukan observasi yaitu pengamatan secara langsung di tempat penelitian sehingga permasalahan yang ada dapat diketahui dengan jelas. Kemudian dilakukan interview yang bertujuan untuk mendapatkan informasi atau data yang dibutuhkan. Selain itu juga dilakukan studi kepustakaan yaitu dengan membaca buku-buku yang menunjang dalam melakukan analisa terhadap data dan informasi yang didapat.

Adapun data-data yang diperlukan dalam penelitian ini adalah daftar kosa-kata Bahasa Jepang - Indonesia

6. Analisa Teknik yang digunakan

Bagian ini bertujuan untuk menganalisis dan memahami teknik yang akan digunakan dalam pengolahan data yang telah diperoleh dari tempat penelitian, terutama pada proses.

7. Implementasi

Setelah dilakukan analisa teknik yang digunakan, maka dilakukan implementasi terhadap software. Jika penerapan sistem sudah berjalan dengan lancar dan akurat, maka sistem dapat diimplementasikan sesuai dengan kebutuhan.

8. Pengujian

Pengujian dilakukan untuk mendapatkan hasil yang sesuai dengan harapan. 


\section{ANALISA DAN PERANCANGAN SISTEM}

\subsection{Analisa Sistem}

Kamus sebagai media pembantu pencarian kata-kata diharapkan dapat digunakan semudah dan sepraktis mungkin. Seorang pengguna membutuhkan pencarian kata yang dapat membantu mengartikan katakata dari informasi yang diinginkannya. Saat ini banyak lembaga pendidikan Bahasa Jepang yang memberikan kemampuan berbahasa kepada peserta didiknya khususnya Bahasa Jepang. Akan tetapi seperti halnya bahasa asing lainnya, sekalipun telah menguasai bahasa tersebut,permasalahan kosa-kata yang tidak diketahui akan tetap dihadapi. Hal ini dapat dimaklumi karena bahasa asing bukanlah bahasa ibu yang berbeda dengan Bahasa Indonesia yang telah terbiasa digunakan, Bahasa Jepang sebagai bahasa asing penggunaannya terbatas, sehingga kosa-kata yang diketahui tentunya terbatas.

Dari penjelasan diatas, nantinya permasalahan akan timbul disaat pembacaan atau pengartian suatu informasi, walaupun dapat membacanya, tetapi tidak semua kosakata yang ada dapat dimengerti. Untuk itu penulis tertarik untuk melakukan sebuah penelitian yang mengangkat permasalahan mengenai bagaimana membangun sebuah sistem yang mampu mengatasi kendala perbedaan bahasa terutama Bahasa Jepang dan mengimplementasikannya dalam sebuah kamus Bahasa Jepang- Indonesia yang dapat dimanfaatkan untuk pencarian kata.

\subsection{Desain Sistem Global}

Desain sistem global memiliki tujuan untuk memberikan gambaran secara umum kepada pengguna tentang sistem yang dirancang. Rancangan sistem mengidentifikasikan komponen-komponen sistem yang akan didesain secara rinci. Desain global dari sistem ini mengacu pada desain aplikasi kamus yang akan memberikan pelayanan pencarian kata secara langsung.

Karena sistem yang dirancang adalah kamus,seperti halnya buku kamus arti kata dan pencarian adalah dengan cara perkata bukan perkalimat. Proses pencarian pertamatama dengan cara pengguna memasukkan kata yang hendak dicari artinya setelah itu cukup dengan menekan enter maka program akan melakukan pencocokan kata yang dientrikan dengan kata yang terdapat dalam database. Jika kata ditemukan maka program akan menampilkan hasil dari pencarian. Akan tetapi apabila kata yang dientrikan tidak ditemukan maka sistem tidak akan merespon.

Meskipun pada sub bab desain global dibahas tentang Aliran Sistem Informasi lama dan baru, Context Diagram, Data Flow Diagram dan Entity Relationship Diagram, namun pada kasus sistem yang dirancang kali ini tidak akan dibahas karena sistem yang dirancang adalah aplikasi kamus dimana tidak ada data/dokumen yang mengalir dari satu entiti ke entiti lainnya. Hanya struktur programlah yang akan dibahas pada desain global ini.

\subsubsection{Struktur Program}

Pada bagian ini akan diuraikan mengenai struktur program untuk menunjang kemampuan aplikasi kamus Bahasa Jepang dengan menggunakanbahasa pemrograman Java. Struktur program merupakan gambaran singkat mengenai bagian-bagian atau menu program yang terdiri dari menu utama dan ditunjang beberapa sub menulainnya.

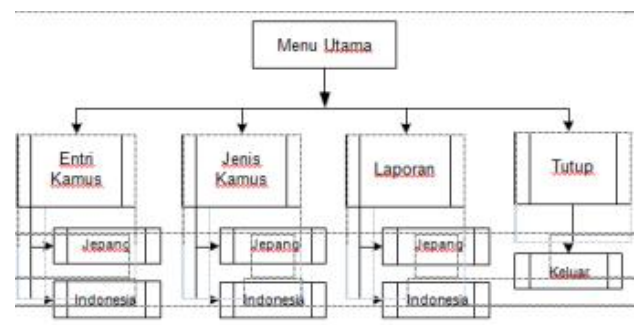

\section{Gambar 4.1. Menu Utama Program}

Pada struktur program diatas, terdapat menu utama dan empatsubmenu yang mana setiap sub menu tersebut memiliki dua pilihan pada sub menu Entri Kamus, Jenis Kamus, Laporan dan satu menu pilihan pada sub menu Tutup yaitu sub menu untuk keluar dari program. Pada menu Entri Kamus digunakan untuk mengentrikan kosa-kata kedalam database. Pada menu Jepang, 


\section{Jurnal Edik Informatika}

ISSN : 2407-0491

E-ISSN : 2541-3716

Penelitian Bidang Komputer Sains dan Pendidikan Informatika

V2.i1(144-151)

pengguna kamus hanya bisa mencari kosakata dari Bahasa Jepang ke Bahasa Indonesia sementara sub menu Indonesia digunakan untuk mencari kosa-kata dari Bahasa Indonesia ke Bahasa Jepang. Menu Laporan terdapat dua sub menu yaitu Jepang dan Indonesia. Sub menu Jepang berisi daftar kosa-kata Jepang-Indonesia yang telah dientrikan kedalam database, sementara submenu Indonesia berisi daftar kosa-kata Indonesia Jepang.

\subsection{Desain Sistem Terinci}

Aplikasi yang dirancang akan diuraikan lebih rinci pada bagian ini. Dengan adanya desain secara rinci maka prinsip kerja dari aplikasi serta komponen-komponen pendukung yang digunakan akan dapat dipahami dengan jelas. Disamping itu, desain terinci merupakan inti sari dari bagian pembahasan sistem agar sistem yang dibangun berjalan sesuai rancangan.

\subsubsection{Desain Output}

Desain output adalah desain tampilan akhir dari aplikasi yang dirancang. Melalui desain output ini pengguna dapat melihat secara utuh tampilan aplikasi yang akan digunakan. Desain output bukanlah tampilan sesungguhnya dari program, melainkan gambaran secara visual yang menyerupai tampilan sesungguhnya. Adapun desain output kamus Bahasa Jepang-Indonesia dapat dilihat pada gambar berikut:

1. Laporan Kamus Jepang Indonesia Pada submenu Laporan Kamus JepangIndonesia, berisi daftar kosa-kata yang berasal dari Bahasa Jepang ke Bahasa Indonesia.

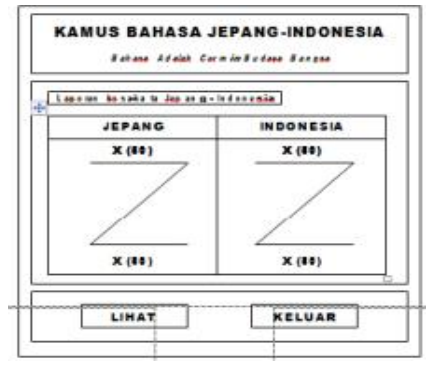

2. Laporan Kamus Indonesia Jepang Pada submenu Laporan Kamus Indonesia-Jepang, berisi daftar kosa-kata yang berasal dari Bahasa Indonesia ke BahasaJepang.

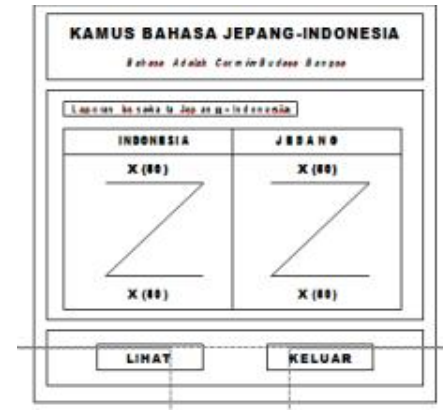

\section{Gambar 4.3. Laporan Kamus Indonesia - Jepang}

\subsubsection{Desain File}

Desain file merupakan perancangan basis data yang akan menampung data entri sehingga dapat dibaca dari program yang telah dirancang, adapun desain file kamus Bahasa Jepang-Indonesia ini adalah sebagai berikut:

\section{Table 4.1. Desain File Jepang}

1. Desain file Jepang

$\begin{array}{ll}\text { Nama database } & \text { : Dkamus } \\ \text { Nama file } & \text { : jepang } \\ \text { Organisasi } & \text { : Index } \\ \text { Field kunci } & \text { : Jepang }\end{array}$

\begin{tabular}{|l|c|c|l|}
\hline $\begin{array}{l}\text { Field } \\
\text { Name }\end{array}$ & Type & Width & Desc \\
\hline Jepang & Text & 50 & Jepang \\
\hline Indonesia & Text & 50 & Indonesia \\
\hline
\end{tabular}

Table 4.2. Desain File Indonesia

\section{Gambar 4.2. Laporan Kamus Jepang - Indonesia}


2. Desain file Indonesia

$\begin{array}{ll}\text { Nama database } & \text { : Dkamus } \\ \text { Nama file } & \text { : indonesia } \\ \text { Organisasi } & \text { : Index } \\ \text { Field kunci } & \text { : Indonesia }\end{array}$

\begin{tabular}{|l|c|c|l|}
\hline $\begin{array}{l}\text { Field } \\
\text { Name }\end{array}$ & Type & Width & Desc \\
\hline Indonesia & Text & 50 & Indonesia \\
\hline Jepang & Text & 50 & Jepang \\
\hline
\end{tabular}

\section{PENGUJIAN DAN MPELEMENTASI}

\subsection{Menu Utama Program}

Pada bab ini akan dijelaskan mengenai menu utama program Kamus Bahasa Jepang-Indonesia,yang terdiri dari satu menu utama dan beberapa submenu. Menu utama akan menampilkan sub-submenu yang ada didalamnya, sehingga seluruh program dapat dijalankan dari satu menu.

Menu utama merupakan bagian pertama yang akan dilalui seorang pengguna ketika program dijalankan. Setelah menu utama tampil, maka pengguna dapat menentukan langkah selanjutnya, baik mengentrikan kosa-kata baru, menggunakan kamus ataupun melihat daftar kosa-kata yang ada. Berikut adalah tampilan menu utama Kamus Bahasa Jepang-Indonesia.

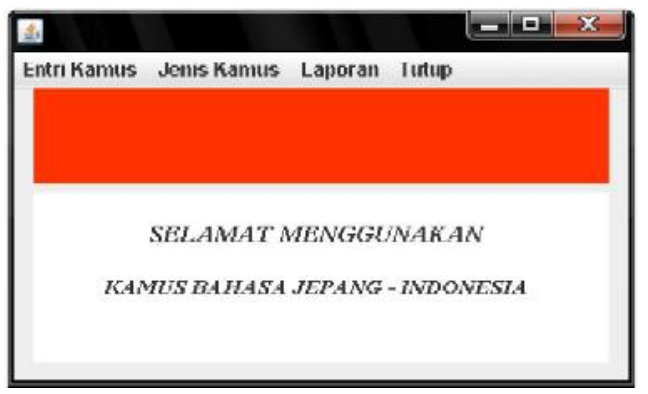

Gambar 5.1. Menu Utama Program

\subsection{Proses Entri Kata Jepang}

Dalam entri Jepang, kosa-kata yang dientrikan adalah kata yang berasal dari Bahasa Jepang lalu di entrikan arti dalam Bahasa Indonesianya. Setelah mengentrikan kedua kata tersebut, lalu klik tombol Simpan, maka akan tampil halaman konfirmasi, apakah data benar-benar akan disimpan, jika diklik tombol Yes maka kosa-kata telah berhasil disimpan kedalam database. Berikut tampilan menu entri Jepang-Indonesia.

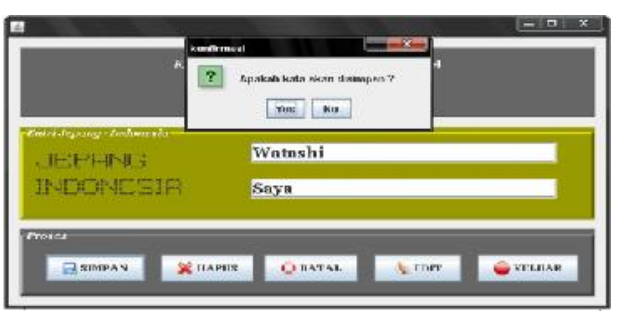

\section{Gambar 5.2. Entri Kata Jepang}

\subsection{Proses Entri Kata Indonesia}

Sementara untukentri Indonesia, kosakata yang diinputkan adalah kata yang berasal dari Bahasa Indonesia kemudian entrikan arti dalam Bahasa Jepangnya. Setelah mengentrikan kedua kata tersebut, lalu klik tombol Simpan, maka akan tampil halaman konfirmasi yang tertulis "Apakah kata akan disimpan?", jika diklik tombol Yes maka kosa-kata akan hilang dari form entri karena telah tersimpan kedalam database.

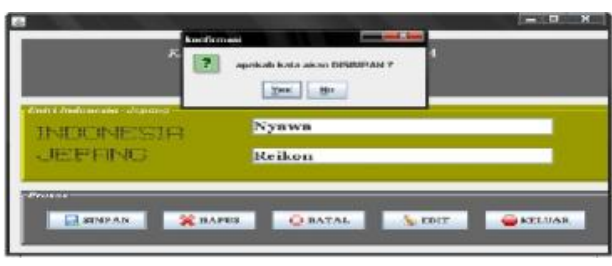

\section{Gambar 5.3. Entri Kata Indonesia}

\subsection{Pencarian Kata Jepang}

Padamenuini, pencarian kata dilakukan untuk mencari arti kata dari Bahasa Jepang kedalam Bahasa Indonesia. Proses pencarian kata diawali dengan menginputkan kata Jepang yang hendak diartikan kedalam Bahasa Indonesia lalu tekan enter, maka kata Indonesia akan ditampilkan, namun jika kata yang hendak dicari tidak ditemukan dalam database, maka program tidak akan merespon. 


\section{Jurnal Edik Informatika}

ISSN : 2407-0491

E-ISSN : 2541-3716

Penelitian Bidang Komputer Sains dan Pendidikan Informatika

V2.i1(144-151)

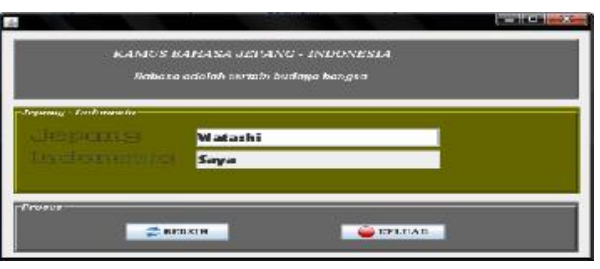

Gambar 5.4. Pencarian Kata Jepang

\subsection{Pencarian Kata Indonesia}

Sedangkan pada menu ini, pencarian kata dilakukan untuk mencari arti kata dari Bahasa Indonesia kedalam Bahasa Jepang. Proses pencarian kata diawali dengan menginputkan kata Indonesia yang hendak diartikan kedalam Bahasa Jepang lalu tekan enter, maka kata Jepang akan ditampilkan, namun jika kata yang hendak dicari tidak ditemukan dalam database, maka program tidak akan merespon.

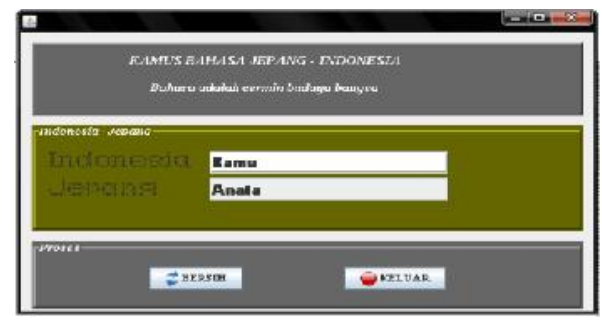

\section{Gambar 5.5. Pencarian Kata Indonesia}

\subsection{Daftar Kosa-kata Jepang}

Daftar kosa-kata Jepang merupakan tampilan daftar kosa-kata dari Bahasa Jepang kedalam Bahasa Indonesia yang telah dientrikan sebelumnya. Untuk menampilkan semua kosa-kata yang ada dalam database, cukup dengan mengklik tombol Lihat, maka semua kosa-kata yang telah ada akan ditampilkan.

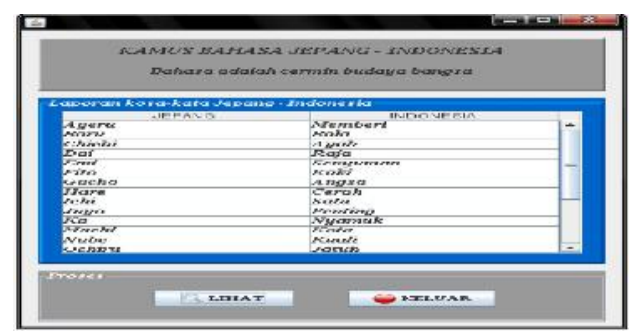

Gambar 5.6. Daftar Kosa-kata Jepang

\subsection{Daftar Kosa-kata Indonesia}

Sedangkan laporan kosa-kata Indonesia merupakan tampilan daftar kosa- kata dari Bahasa Indonesia kedalam Bahasa Jepang. Untuk menampilkan semua kosa- kata yang ada dalam database, cukup dengan mengklik tombol Lihat, maka semua kosa-kata yang telah ada akan ditampilkan.

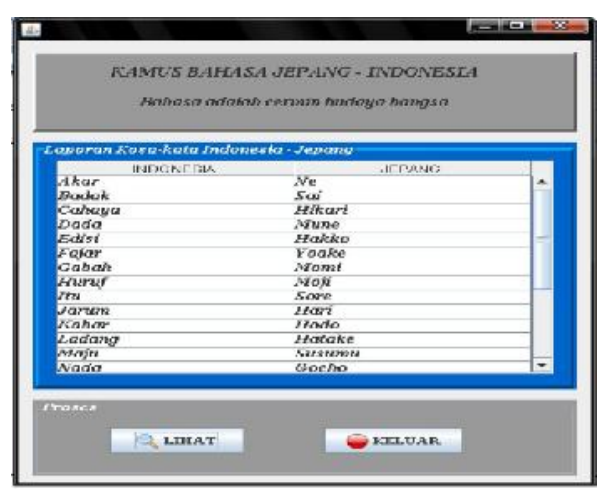

\section{Gambar 5.7. Daftar Kosa-kata Indonesia}

\section{PENUTUP}

\section{a. Kesimpulan}

Adapun kesimpulan yang dapat diambil dari pembahasan skripsi ini adalah:

1. Aplikasi kamus Bahasa JepangIndonesia dapat membantu pengguna dalam mencari kosa-kata Bahasa Jepang dan Indonesia dengan mudah

2. Dengan menggunakan database yang baik, maka pengguna dapat langsung menambah daftar kosa-kata kedalam database melalui form entri

3. Dengan menggunakan bahasa Pemrograman Java, maka pengguna juga dapat melakukan perbaikan terhadap kata yang sudah tidak relevan lagi akibat perkembangan bahasa

\section{b. Saran}

Demi kesempurnaan program ini, maka saran penulis bagi para pembaca dan perancang program sebagai berikut:

1. Ribuan bahkan jutaan kosa-kata yang ada membutuhkan waktu untuk menginputkannya. Penulis berharap seiring berjalannya waktu, database kamus yang ada dapat ditambah. Melalui sistem update, database kamus perlahan 
dapat dilengkapi.

2. Kebutuhan akan software penerjemah yang lebih memudahkan terutama pengguna yang sama sekali tidak mengerti Bahasa Jepang. Diharapkan pada masa yang akan dating kamus Bahasa Jepang Indonesia ini juga dapat menyediakan kemampuan tersebut.

3. Salah satu faktor penarik pengguna untuk menggunakan kamus Bahasa JepangIndonesia ini adalah tampilan grafis. Penulis menyadari tampilan kamus Bahasa Jepang-Indonesia ini masih belum cukup untuk bersaing. Oleh karena itu pada perancang selanjutnya dapat meningkatkan tampilan grafis dari kamus ini.

\section{DAFTAR PUSTAKA}

Ibnu Rachman Chalid. (2009). "Aplikasi Audio Steganografi untuk Melindungi Data Menggunakan Bahasa Pemrograman Java". Jakarta.

Jasman Pardede. (2013). "Implementasi Metode Generalized Vector Space Model Pada Aplikasi Information Retrieval. Bandung.

Mila Tasmawati.(2008). "Aplikasi Konversi Regular Grammar Menjadi Ekspresi Regular dengan Menggunakan Bahasa Pemrograman Java".Jakarta.

Nihongo.(2010). “Analisis Kesalahan Penggunaan Ungkapan Yari-Morai dan Pemerolehannya Pada Pembelajar Bahasa Jepang”.Jakarta.

Nugroho, Bunafit. 2010. "Membuat Aplikasi Database dengan Java, MySql, dan Netbeans". Gramedia. Jakarta.

Pitri Haryanti. (2012). "Analisis Perbedaan Takusan dan Ooi". Bandung. 